\title{
Gender Equality in the Information Systems and Technology Fields: A Com- prehensive Diagnosis at the School of Engineering of the University of Minho
}

\section{Prof. Rosa Maria Castro Fernandes Vasconcelos, University of Minho}

Rosa Maria de Castro Fernandes Vasconcelos is a Associate Professor at the Department of Textile Engineering since 2005. Degree in Textile Engineering by the University of Minho. Professor at the University of Minho since 1984. PhD in Engineering -Technology and Textile Chemistry by the University of Minho in 1993. Rieter Award, 1993.

Responsible for several curricular units in the integrated study cycles in Textitle Engineering and Engineering and Industrial Management, in the 1st cycle course of Design and Fashion Marketing, and also in the 2nd cycle courses of Fashion Design and Communication, Textile Chemistry, Advanced Textiles and Design and Marketing.

Head research and research member of several R\&D projects, has presented as main author or co-author many dozens of scientific journal papers and communications in international conferences.

President of the Pedagogical Council of the School of Engineering since 2011 and Vice-Dean of School of Engineering

\section{Victor F. A. Barros, University of Minho}

Victor F. A. Barros, Ing.-Paed IGIP (ORCID 0000-0002-7318-8257) is Researcher Fellow at Algoritmi Centre/University of Minho (Portugal) working on H2020 Project titled "Gender Equality Plans for Information Sciences and Technology Research Institutions, EQUAL-IST". He is Member of Intersociety Cooperation Committee, Standing Committee of the IEEE Education Society; Vice President of Brazilian Chapter of Association of Information Systems (BRAIS); Vice President of the Portuguese Chapter of the IEEE Women in Engineering (IEEE WiE); and Associate Editor of Directory of Open Access Journals (DOAJ). He is Editor-in-Chief of Brazilian Journal of Education, Technology and Society (BRAJETS) and Associate Editor of Journal of Information Systems and Technology Management (JISTEM). He is titled "Engineering Educator Professor" by the IGIP (International Society for Engineering Pedagogy) and Professor of the IGIP Engineering Educator Certificate Program. He is Executive Director at International Institute of Education (IIE) and Executive Secretary of Science and Education Research Organization (COPEC). He is President of Brazilian Citizen Council of Porto/Portugal (CCBP) and Executive Secretary of the Brazilian Citizen Abroad Council (CRBE) linked to the Brazilian Ministry of Foreign Affairs (Itamaraty). He is Publication Chair/Member of Organization of the IEEE EDUNINE and more than 10 others international conferences around the world. He is involved in more than 10 research projects and He is Collaborator Researcher of the several Research Groups, namely: ISTTOS at Algoritmi Centre of the University of Minho (Portugal); NEPIAP and NEPEC at IFG (Brazil); LDGM at UNESP (Brazil); TECSI and OMTID at USP (Brazil).

\section{Prof. Luis Alfredo Martins Amaral P.E., University of Minho}

Born in 1960 is Associate Professor at Department of Information Systems in the School of Engineering of University of Minho. Researches and teaches in the areas of Information Systems Planning, Information Systems Management and the Information Society, especially in the field of Public Administration. Chairman of the Board of the GCC - Computer Graphics Center since 2005. Pró-Rector of University of Minho between 2006 and 2009. President of the National College of Informatics (Order of Engineers) since 2010.

\section{Prof. Emilia Rodrigues Araújo, University of Minho}

Is professor at the Department of Sociology at the Institute of Social Sciences, in the University of Minho. She holds a PhD in Sociology, since 2005. She teaches in the field of methodologies, culture and technoscience and has been researching on sociology of time, mobilities and science. She was the Principal 
Investigator of the project "Mobiscience - trajectories of Portuguese researchers and knowledge circulation. She has many international and national publication on the topics of gender, time uses, mobilities and lifestyles. She has also several consultancy participations on projects concerning cities, mobilities and sustainability. She is a member of the Portuguese Sociology Association and of ECREA. Currently she is serving as vice-president of the Institute of Social Sciences, University of Minho.

\section{Dr. Isabel Ramos, University of Minho}




\title{
GENDER EQUALITY IN THE INFORMATION SYSTEMS AND TECNHONOLOGY FIELDS: A COMPREHENSIVE DIAGNOSIS AT THE SCHOOL OF ENGINEERING OF THE UNIVERSITY OF MINHO
}

\begin{abstract}
Gender equality in academia and science has been a central theme in several scientific studies around the world. Over the last few years, there has been an extensive literature production on the explicit and implicit processes that drive gender inequalities and make them persist over time.

In contexts of increasing mobility, globalization and cultural change, it is urgent that science and education policies, defined in the context of Universities and their human resources (including teaching, non-teaching staff as well as students), recognize the existence of gender inequalities and promote effective measures for its eradication, in a collective and participatory approach.

Despite the production of literature attesting the existence of gender inequalities in academia, which documents processes of segregation and discrimination that affect the various participants of the organization as well as a set of methodological proposals to overcome them, it has not proved sufficient to change the reality of practices in teaching and research institutions

Since gender inequality is a transversal problem and holds implications for the University as a whole, and individually for the people that compose it, this study documents the initial measures implemented at Engineering School, as part of Project EQUAL_IST- Gender Equality Plan for Information Sciences and Technology Research Institutions, which is being carried out by teams in several European countries, and aims, mainly, to study and intervene in the advancement of gender equality in the area of Technology and Information systems.
\end{abstract}

\section{Introduction}

Several studies have pointed out the need to foster a diagnosis and an intervention concerning gender equality in academic contexts (1-14). Studies carried out by Amâncio (9-10) demonstrated the existence of gender patterns in access and mobility processes to which are linked gender biases and stereotypes that place women on the "margins" of knowledge production. Recent studies developed in Portugal (15) describe how women and men are socially perceived according to essentialist dichotomous principles, which favour the invisibility and devaluation of women.

Legislation on the promotion of gender equality in educational institutions in Portugal is relatively recent compared to other European countries and it is the result of a very persistent and onerous work of several actors among them women who took the subject as a purpose for the development of Portugal.

In practice, Decree-Law 392/70 (September 20, 1979) regulated Equal Opportunities for the first time, and, since then, a series of legislative initiatives with practical effect has been carried out, 
with ramifications for the context of science and higher education. Of particular notice are the creation and implementation of the 'Commission for Equality in Labour and Employment' and the 'Commission for Citizenship and Gender Equality', the two main agents for the implementation of the national strategy for equality and non-discrimination. Currently, the existing framework establishes a set of norms for companies and labour organizations to comply with principles for reconciling work and family life, parental leave, as well as incentives for the creation of gender equality plans, but the methodology adopted and its implementation is still left to the discretion of each institution. One of the most recent legislative incursions consisted of mandatory quotas for women in public companies.

It is known that, in Portugal, the main barriers lie in cultural and institutional issues which lead to the refusal to admit gender inequality, even by those who suffer with it (16). Only a few Universities are currently backed up by formal gender equality plans and the awareness of this problem is relatively poor, as shown by the results published (17). Even though there are projects going on in other universities, like in University of Minho (Braga) (18), in the School of Education of Porto (Porto) and in the University of Aveiro (Aveiro); the only Universities which have already implemented gender Equality plans are the University of Beira Interior - UBIgual - "Gender Equality plan of the University of Beira Interior"; and the University of Trás-os-Montes e Alto Douro (Vila Real) - "UTAD rhymes with Equality"- Gender Equality Plan at UTAD. More recently, also ISCTE implemented a gender equality plan, through SAGE project.

This text focuses on the actions taken to implement the gender Equality plan at the University of Minho, which was based on a diagnosis study, carried out for two years, using several methodologies which are highly participatory.

The research project to which we refer to is commissioned by Horizon 2020 and encompasses different teams in several European countries, namely Italy, Germany, Liechtenstein, Finland, Lithuania, Ukraine and Portugal. During the last two years, several research techniques were mobilized to collect qualitative and quantitative information concerning several variables that may explain gender inequality. As stated, a participatory research path was taken, which involved indepth interviews as well as focus groups and observation. The outputs of this work resulted in a gender equality plan (GEP) for the University of Minho, involving the participation of different institutional representatives.

\section{Notes on the Method}

The first strategic stage for the creation of the Gender Equality Plan of the University of Minho was a diagnosis study made at the School of Engineering. This strategic analysis was organized in 05 steps: Establishing the Working Group (Step 1); Collecting Internal Data (Step 2); Qualitative analysis: interviews (Step 3) and Workshops (Step 4); and Definition of Challenges and Actions (Step5). 


\section{Establishing the Working Group (Step 1)}

Project EQUAL_IST- Gender Equality Plan for Information Sciences and Technology Research Institutions is the first initiative of the School of Engineering that discusses Gender Equality internally. The process of getting people involved in the project activities was quite complex. It required several contacts to ensure the participation of key people inside the organization, selected by their understanding of gender issues or by their internal power so that access to information would be easier.

The first activity consisted, therefore, in establishing the working group, composed by stakeholders representing all interested parts (professors, researchers and students), but also all Teaching and Research Units of University of Minho. (Table 1)

Table 1-Working Group members of the Project EQUAL_IST

\begin{tabular}{|c|c|c|c|c|c|c|}
\hline & \multicolumn{2}{|c|}{ Participants } & \multicolumn{4}{|c|}{ UOEI } \\
\hline & \multirow{2}{*}{$\begin{array}{l}\mathrm{M} \\
1\end{array}$} & \multirow[t]{2}{*}{ F } & \multicolumn{2}{|c|}{ School of Engineering } & \multicolumn{2}{|c|}{ Others } \\
\hline Researchers & & & 1 & 2 & - & 7 \\
\hline $\begin{array}{l}\text { Professors } \\
\end{array}$ & 5 & 16 & 4 & 7 & 1 & 9 \\
\hline Students & 5 & 5 & 5 & 3 & - & 2 \\
\hline Total & $11(27 \%)$ & $30(73 \%)$ & $10(24,4 \%)$ & $12(29,2 \%)$ & $1(2,4 \%)$ & $18(44 \%)$ \\
\hline
\end{tabular}

The working group members provided all the relevant information during the quantitative data analysis, the interviews carried out in all the University of Minho (Step 3) as well as in the workshops developed at the School of Engineering (Step 4).

It was considered relevant to involve men in discussion, so that the project would be seen as a project that really focuses on gender equality as whole (men \& women). By doing so, we would also create awareness about the perceived challenges for both men and women. However, their involvement was not easy. Only eleven came to participate in the working groups.

Another challenge we had to face, during the process, was concerned the agenda - finding a common timetable that would allow the members of the working group to meet and work together. To overcome this issue, we divided the working group into several subgroups; this division facilitated participation and allowed us to focus on particular perspectives from each of the profiles involved: Students, Researchers, Teachers and Leaders. This approach implied that the group meetings, as well as the interviews, had to be extended over a longer period, what, on the other hand, turned out to be beneficial, thus allowing greater internal dissemination of the project

The working groups allowed to confirm the general unawareness of gender inequality at the university. However, if at the beginning of the discussion, people argued that gender issues at the University were almost irrelevant (since no problems had been reported), in the course of the debate people started to reflect more about the subject, admitting several situations of inequality due to gender.

The next challenge consisted in discussing possible solutions for the identified issues, which turned out to be also very difficult, not only to find solutions but also to recognize good practices in other institutions. 
During these group meetings, and with the consent of all the participants, notes were taken by one of the researchers, which were later rewritten into summaries and conclusions, that after being validated by all the participants, became formal records kept by the project team.

\section{Collecting Internal Data (Step 2)}

The collection of the necessary data to produce the report was not an easy task. The main reasons for these difficulties were related either to bureaucracy or to the non-integration of information systems.

However, all these problems were minimized by the support of all the working group. Each member of this working group has been selected taking into account either his/her position inside the University, his/ her recognition in the scientific field or his/her interest in the subject; forming, therefore, a strategic group for the effective conduction of the Project inside the University.

The collaborative efforts that were required to gather data and fill in data gaps found, ended up strengthening the group's cohesion. And this was the basis to make group members more willing to find time for meetings and interviews.

Moreover, we were able to disseminate the project internally to a point in which we have developed greater openness to explore different settings and implement some structural changes that will encourage more gender equality at the University.

\section{Qualitative Analysis: Interviews (Step 3)}

The Qualitative analysis consisted of Interviews and Workshops. 12 participants were interviewed, including 07 Women and 05 Men, namely:

At Rectory level:

- Vice Dean of Internationalization (W)

- Director of Internationalization (W)

- Director of the Inclusion Office (M)

- Chief of the Central Institutional Communication Office (W)

- Member of the Central Institutional Communication Office (M)

At School of Engineering level:

- Vice Head of the School of Engineering (W)

- Director of the Information Systems Department (M)

- Full professor of the Information Systems Department (M)

- Director of the Doctoral Program in Information Systems and Technology (W)

- Member of the Communication Office of the School of Engineering (W)

- Member of the Communication Office of the School of Engineering (M)

- Researcher of Doctoral Program in Information Systems and Technology (W) 
For the interviews the following questions were used:

1. Which do you consider to be the main issues regarding gender equality within your institution in the area of services for international students?

2. In your opinion, how and to what extent are they perceived?

3. On the other hand, which are the most significant achievements in terms of gender equality? And which dedicated resources and mechanisms/committees are available in your institution?

4. In your opinion, which are possible actions/strategies that could be useful to apply in order to improve gender equality? And which main obstacles do you envisage for their application?

5. Please, describe if there is any ongoing or planned future action to improve gender equality in your area.

6. Any other remarks.

The first challenge faced when we proposed the interview to the participants was finding a suitable schedule to perform it

Due to the interviewees' unfamiliarity with the gender equality theme, project researchers had to give some examples of what was considered gender inequality in other contexts. A certain curiosity and surprise were noticed at the beginning of the interview, which then led to more reflexivity throughout the rest of the interview.

\section{Qualitative Analysis: Workshops (Step 4)}

In total, five workshops were performed, totalling 18 women and 16 men. Some of the information gathered from the interviews was used to prepare workshops agendas, like Historical facts of the University, mainly about programs, student awards and other internal situations that showed lack of awareness about gender discrimination. These contextual facts were used as guidelines for planning the interactions, schedules and venues. All workshop sessions were organized according to an agenda containing four main parts:

\section{Project EQUAL_IST-Project Explanation}

A brief explanation about the purpose of the EQUAL_IST Project and the workshop was presented.

\section{Presentation of a timeline}

In order to draw participants' attention to the topic, the project team showed a timeline with information about the changes that occurred in gender relations in Portugal after the democratic revolution in 1974. In addition, the project team also added some data showing the evolution of the number of students per gender at Minho University and in Portugal.

After this short introduction, the participants were divided into groups and invited to read the information posted on the timeline and examine the images and other graphs displayed on it. 
Participants were then invited to share their opinions about the information displayed on the timeline, to comment on the changes that they considered more important more important and to share their appreciation on that.

Participants showed great interest in the timeline explanation, what indicated their level of ignorance about historical fights concerning gender inequality in Portugal.

\section{Questionnaire about general challenges}

After the timeline exercise, participants were asked to reply, in group and individually, to a previously prepared questionnaire. This questionnaire had a list of sentences addressing some of the main challenges to gender equality in the academy and higher education Institutions in general.

Participants were first asked to indicate their level of agreement with each sentence listed. Then, individually, they were asked to classify them according to their seriousness and incidence inside the University of Minho.

Individual answers were then discussed in the group and a Cartesian plan was developed to gather rhe achieved consensus. The discussion brought about further understanding of gender issues inside the University of Minho.

At the end of this activity, a facilitator asked the participants to name the most serious problems/challenges that they have identified and to relate them to the main gender inequality issues they had encountered at the University of Minho.

\section{Short list of good practices}

After the discussions in 3, participants were asked to work on possible changes and/or good practices to be implemented at University of Minho in order to overcome possible gender issues they had identified. Therefore, participants were asked to prioritize five structural measures to be implemented. As in the previous phase, they were asked to say to what extent they agreed with each priority. Although the activities were developed within the group, in the end, each participant was able to share their individual answers. To conclude, the facilitator shared some insights that emerged from the group discussion.

\section{Definition of Challenges and Actions (Step 5)}

During this stage and after the analysis of all the previous stages, we highlighted those which were the main challenges (i.e. lack of time, attention, interest, other) and resistances, if any (both explicit, i.e. personal disagreement expressed against the goals of the project and its background statements/analysis, and implicit, i.e. denial or diminishing strategies, etc.) faced during the four previous stages. Furthermore, we also highlighted the main actions and the best practices that we registered during all the previous stages. All these challenges and actions were classified and discussed to elaborate the GEP. 


\section{Construction of a Code of Conduct for diversity and gender equality}

The Code of Conduct, an integral part of the Gender Equality plan, establishes the main guidelines for the practice of Gender Equality at the University of Minho. These guidelines were developed with the purpose of generating and consolidating awareness for gender equality, serving as a tool to identify the most structuring areas and dimensions of the university and academic life.

The Code of Conduct embraces eight (8) main topics, which were developed with the participation of different actors from diverse hierarchical positions:

1. Gender parity is a priority.

2. The quality and access to information.

3. The policy of recruitment and evaluation

4. The policy of performance evaluation in all working contexts

5. The policy of interpersonal and inter-institutional interaction

6. The constitution of a culture of Gender Equality

7. The effective recognition of the principles of freedom and diversity

8. The revision of this Code

The code of conduct aims to contribute for a culture of gender accountability in the organization, integrating norms and criteria of conduct and decision as a way to help to create a climate of integrity in the University of Minho, contributing to its positive image. In addition, the Code of Conduct will contribute to the implementation of a set of best practices that promote equal opportunities in universities.

This Code of Conduct opens the way to the development of this structuring principle for the university's daily life and is a fundamental pillar for the construction of the University as spaceof knowledge, individual growth and citizenship.

\section{Example of GEP action:Internal event for Secondary School Students}

The University of Minho organized an event to foster the interest of high Schools students for choosing engineering and technological fields as their future professional paths. By giving as examples female professionals working in the fields of Engineering and Technologies, the events' main aim was to increase students' awareness that Engineering a gendered. Seven workshops were held, reaching a total of 147 students (113 Men and 34 Women).

\section{National Gender Equality Observatory (ObservaGenero)}

The project includes the ObservaGenero is a national gender observatory which aims to promote gender equality and provide strategic gender indicators and analytical tools to develop policies and actions related to the promotion of gender equality.

For the development of this action, a working group was established and a set of activities were defined. These activities were divided into two stages: the first stage consisted of collecting information on the topic of gender equality in Portugal, regarding different aspects - Education, 
Politics, Industry and Services. The second stage consisted of the development of the necessary platform to support the online observatory.

Regarding the first stage, the following information was collected:

1. Universities that have a Gender Equality Plan in Portugal

2. National agencies directly and/or indirectly related to Gender and Diversity issues

3. Legislation directly and/or indirectly related to issues of Gender and Diversity

4. Initiatives on Gender Equality in the Labour Market, especially concerning the

Job opportunities for new graduates

5. National Projects on Gender Equality

The collected information was used to develop a timeline and some infographics illustrating the main developments of Gender Equality that occurred in Portugal over the years

Moreover, the Observatory platform will also include information collected during the carried development of the GEP and information about gender equality in Portugal, particularly:

- Portuguese Legislation and Public Policies

- Collaborative Map with Initiatives on Gender Equality Plans in Portugal

- Infographics of the diagnosis study performed at University of X with students, Teaching and non-teaching staff.

\section{Conclusion}

Each step of this trajectory - from the design to the implementation - of the Gender Equality Plan at the University of Minho - helped us to identify important challenges that have to be faced in order to reduce gender disparities and to generate contexts that allow the implementation of measures to overcome these challenges.

The implementation of the GEP has been instrumental and served to promote internal discussions, identify researchers in the University that are experts in the field, facilitate multidisciplinary collaboration and raise awareness to the topic among the community of the University of Minho.

In general, all actions/activities developed by the University of Minho are in line with what is defined in the GEP. The GEP of the University of $X$ has foreseen the development of a total of 61 activities, distributed by 25 actions. 16 of all the activities have already been completed (26,2\%); 32 are in progress $(52,5 \%)$ and 13 are planned $(21,3 \%)$. Only 15 activities are behind schedule, due to delay in receiving third parties' responses, in particular from the Rector's team, Schools and Institutes' deans, and research centres, as well as due to some structural changes at the University. Nevertheless, all the delayed activities will be completed during the second iteration of the GEP implementation.

It is also important to highlight a set of qualitative outcomes that occurred at the University of Minho with the implementation of the GEP:

- The encouragement of more female speakers in the events organized by the University of Minho; 
- More events involving various stakeholders, including government representatives and representatives from all education and research units of the University of Minho, to discuss gender equality challenges and opportunities;

- More national and international funding opportunities to ensure the sustainability of the activities envisioned by the GEP which were initiated within the EQUAL_IST Project.

Some internal and external barriers still need to be broken and the difficulty of promoting measures to raise the awareness of problems associated with gender inequality - from recruitment and performance evaluation to professional relationships - are still real and must be overcome. For this reason, this project integrates a strong dimension of action research, encouraging the participation of all Schools and Institutes of the University of Minho, uniting researchers and institutional representatives equally committed to the purpose of promoting gender equality at the University of Minho.

\section{Acknowledgement}

This work was partly funded by FCT - Fundação para a Ciência e Tecnologia within the Project Scope: "Project UID/CTM/00264/2019 of 2C2T - Centro de Ciência e Tecnologia Têxtil,; "Project UID/CEC/00319/2019" and COMPETE: POCI-01-0145-FEDER-007560; project $\mathrm{UID} / \mathrm{CCI} / 00736 / 2013$.

\section{References}

[1] Bradley, K. (2000). The incorporation of women into higher education: Paradoxical outcomes? Sociology of education, 73, 1-18.

[2] Brooks, G. R. (2001). Masculinity and men's mental health. Journal of American College Health, 49(6), 285-297.

[3] Fox, M. F., \& Stephan, P. E. (2001). Careers of young scientists: Preferences, prospects and realities by gender and field. Social studies of Science, 31(1), 109-122.

[4] Lawless, J. L., \& Fox, R. L. (2005). It takes a candidate: Why women don't run for office. Cambridge University Press.

[5] Stewart, A. J., Malley, J. E., \& LaVaque-Manty, D. (2007). Transforming science and engineering: Advancing academic women. University of Michigan Press.

[6] Ceci, S. J., Williams, W. M., \& Barnett, S. M. (2009). Women's underrepresentation in science: sociocultural and biological considerations. Psychological bulletin, 135(2), 218

[7] Gaughan, M., \& Bozeman, B. (2016). Using the prisms of gender and rank to interpret research collaboration power dynamics. Social Studies of Science, 46(4), 536-558.

[8] Pereira, M. D. M. (2010). Higher Education Cutbacks and the Reshaping of Epistemic Hierarchies: An Ethnography of the Case of Feminist Scholarship.Sociology, 44(2), 287-304. 
[9] Amâncio, L. (1993). Género: representações e identidades. Análise das representações do masculino e do feminino e sua articulação com as identidades. / Gender: Representations and Identities. Analysis of the male and female representations and their articulation with identities [10] Amâncio, L., \& Ávila, P. (1995). O género na ciência. A Comunidade Científica Portuguesa nos Finais do Século XX, Oeiras, Celta Editora, 135-162. / Gender in Science. The Portuguese Scientific Community at the end of the 20th century.

[11] Delicado, A., \& de Almeida Alves, N. (2013). "Fugas de Cérebros", "Tetos de Vidro" e "Fugas na Canalização": mulheres, ciência e mobilidade. In Araujo, E.Fontes, M. \& Bento, S. (2012). Para um debate sobre mobilidade e fuga de cérebros (8-32), CECS- Publicações/eBooks. / "Brain Leaks", "Glass Ceilings" and "Pipe Leaks": women, Science and mobility. In Araújo, E. Fontes, M. \& Bento, S. (2012). For a debate on mobility and brain leaks (8-32), CECSPublicações/eBooks

[12] Almeida, L. S., Guisande, M. A., Soares, A. P., \& Saavedra, L. (2006). Acesso e sucesso no ensino superior em Portugal: Questões de género, origem sócio-cultural e percurso académico dos alunos. Psicologia: Reflexão e Crítica, 19(3). / Access and Success in Portuguese Higher Education: Gender issues, Socio-cultural origin and academic paths of Students.

[13] Santos, G. G. (2004). O género e a carreira académica: Uma análise das barreiras organizacionais. Comportamento Organizacional e Gestão, 10, 241-260. / Gender and Academic Career: an analysis of organizational barriers.

14] Araújo, E., \& Fontes, M. (2013). A mobilidade de investigadores em Portugal: Uma abordagem de género. Revista iberoamericana de ciencia tecnología y sociedad, 8(24), 9-43. / The mobility of Researchers in Portugal: a gender approach.

[15] Sales-Oliveira, C., Villas-Boas, S., \& Las-Heras, S. (2016). Estereotipos de género y sexismo en docentes de educación superior. Revista iberoamericana de educación superior, 7(19), 22-41. / Gender and Sexism Stereotypes in Higher Education Teachers.

[16] Sales-Oliveira, C. (2014). Still Driven Mobility patterns and gender roles in Portugal. CIES e-Working papers ISSN 1647-0893.

[17] Sales-Oliveira, C., Morgado, C. (2016). Plano UBIgual - Relatório de Igualdade de Género da UBI, FCSH Centre for Research and Studies in Sociology. /UBIgual Plan - Gender Equality in UBI Report

[18] Barros, V. F. A., Vasconcelos, R. M., Araújo, E., Amaral, L., and Ramos, I. (2018). “A positive Perspective to the Implementation of a Gender Equality Plan: A Question of Design, Time and Participation," in 2018 IEEE Frontiers in Education Conference (FIE), IEEE Education Society. 